\title{
EKSPERIMENTASI MODEL PROJECT BASED LEARNING (PjBL) DAN COOPERATIVE LEARNING TIPE GROUP INVESTIGATION (GI) PADA MATERI POKOK BANGUN RUANG DITINJAU DARI KECERDASAN EMOSIONAL SISWA KELAS VIII SMP NEGERI SE-KOTA METRO LAMPUNG
}

\author{
Juitaning Mustika ${ }^{1}$, Tri Atmojo Kusmayadi ${ }^{2}$ Riyadi $^{3}$ \\ ${ }^{1,2,3}$ Prodi Magister Pendidikan Matematika, FKIP Universitas Sebelas Maret Surakarta
}

\begin{abstract}
The objective of research was to investigate the effect of learning models on Mathematics learning achievements viewed from students' emotional intelligence. The learning models compared were PjBL, GI and direct learning model. This study was a quasi experimental research with a $3 \times 3$ factorial design. The population of research was all of the VIII graders of Junior High Schools in Metro City. The sample was taken using stratified cluster random sampling. The sample of research consisted of 238 students with details 80 students for the experiment 1, 80 students for experiment 2 and 78 students for control classes. The instruments used for collecting data were mathematics learning achievement test and student EI questionnaires. The results of this research were as follows: (1) the use of the PjBL model couldresult better learning achievement than both GIandthe direct learning. The use of GI could result better learning achievement than the direct learning model, (2) Students with high EI, resulting better learning achievement than students with moderate or low EI, and students with moderate EI hadbetter learning achievement than students with low EI, (3) For those students with high and moderate EI, the PjBL modelresulted better learning achievement than direct learning model, while the PjBL models gave the same learning achievement asGI, and the GIgavethe same learning achievement as the direct learning model. For students with low EI, PjBL, GIand direct learning model gave the same learning achievement, (4) In learning using PjBL model, students with high EI had better learning achievement than students with low EI, and students with moderate EI had better learning achievement than students with low EI, while students with high EI had the same learning achievement as students with moderate EI. On learning using GImodel, students with a high EI had better learning achievement than thosewith low EI, while students with high EI had the same learning achievement as students with moderate EI and students with moderate EI had the same learning achievement as students with a low EI. Direct learning model gave the same effect on learning outcomes among students who had high, moderate and low EI.
\end{abstract}

Keywords: Project Based Learning (PjBL), Group Investigation (GI), Direct learning andEmotional Intelligence (EI).

\section{PENDAHULUAN}

Perkembangan ilmu pengetahuan dan teknologi dewasa ini menuntut adanya peningkatan kualitas sumber daya manusia. Potensi sumber daya manusia merupakan aset nasional sekaligus sebagai modal dasar pembangunan bangsa. Potensi ini hanya dapat digali dan dikembangkan secara efektif melalui pendidikan, yang dikelola secara serasi dan seimbang dengan memperhatikan pengembangan potensi siswa secara utuh dan optimal. Lembaga pendidikan dituntut untuk berperan aktif dalam mengembangkan intelektual dan emosional bangsa secara optimal agar dapat meningkatkan kualitas, harkat, dan martabat bangsa. 
Salah satu usaha untuk meningkatkan kualitas pendidikan adalah dengan meningkatkan kualitas pendidikan matematika. Menurut Ignacio et al. (2006: 16), "Learning mathematics has become a necessity for an individual's full development in today's complex society”. Belajar matematika sudah menjadi kebutuhan bagi kemajuan seseorang di masyarakat yang kompleks sekarang ini. Matematika salah satu mata pelajaran yang menjadi dasar bagi ilmu pengetahuan yang lain karena di dalamnya terdapat kemampuan berhitung, logika, dan berpikir.

Berdasarkan PAMER Tahun Pelajaran 2013/2014, rata-rata nilai Ujian Nasional (UN) mata pelajaran matematika untuk SMP Negeri di Kota Metro sebesar 5,58 sedangkan rata-rata nilai matematika tingkat Provinsi sebesar 5,71. Hal tersebut menunjukkan adanya kesulitan dalam pembelajaran matematika terutama bagi siswa di Kota Metro, khususnya pada materi bangun ruang. Apabila dibandingkan dengan materi pokok yang lain, materi bangun ruang memiliki persentase daya serap lebih kecil yaitu sebesar 54,58\% jika dibandingkan dengan persentase daya serap materi peluang sebesar $56,43 \%$ di Kota Metro.Hal ini menunjukkan bahwa masih banyak siswa yang mengalami kesulitan dalam pelajaran matematika khususnya materi bangun ruang di Kota Metro.

Seiring dengan berlakunya Kurikulum Tingkat Satuan Pendidikan (KTSP), guru merupakan faktor penting yang memberikan pengaruh besar terhadap proses dan hasil belajar, bahkan sangat menentukan berhasil-tidaknya siswa dalam belajar. Pemilihan model pembelajaran dalam pembelajaran matematika oleh gurujuga sangat menentukan keberhasilan proses pembelajaran. Pada dasarnya model pembelajaran yang tepat menjadikan siswa mengerti dan memahami secara optimal dalam suatu pembelajaran. Pada kenyataannya, pembelajaran matematika di sekolah masih dilakukan dengan model pembelajaran langsung yang berpusat pada guru. Guru memposisikan diri sebagai yang mempunyai pengetahuan dan siswa sebagai objek yang dianggap tidak tahu atau belum tahu apa-apa. Akibatnya siswa kurang mempelajari materi dan cenderung pasif dalam pembelajaran.

Solusi yang diberikan untuk menyelesaikan masalah tersebut yaitu model pembalajaran yang sesuai materi bangun ruang dan membuat siswa menjadi aktif serta kreatif.Model pembelajaran untuk masalah tersebut adalah menggunakan model Cooperative Project Based Learning (PjBL) dan Group Investigation (GI). Menggunakan model PjBL, karena model ini mengajak siswa untuk kreatif menghasilkan sebuah karya yang berhubungan dengan kehidupan sehari-hari pada benda yang berbentuk bangun ruang. Selanjutnya model GI membutuhkan materi pembelajaran yang memiliki sub topik yang saling independen, karena dalam setiap kelompok siswa memiliki topik pembelajaran yang berbeda-beda. Pada materi pokok bangun ruang, siswa dapat 
merancang proyek dan materi ini memiliki beberapa sub topik, sehingga model Project Based Learning (PjBL) dan model Group Investigation (GI) dapat diterapkan dalam materi bangun ruang.

Hornby (2009) menyatakan bahwa cooperative learning merupakan pembelajaran yang efektif dalam meningkatkan prestasi belajar siswa untuk segala usia dan unsur-unsur kuncinya adalah akuntabilitas individu serta saling ketergantungan positif.Model PjBL adalah model pembelajaran yang menggunakan proyek/kegiatan sebagai media. Siswa melakukan eksplorasi, penilaian, interpretasi, sintesis, dan informasi untuk menghasilkan berbagai bentuk hasil belajar (Permendikbud no.58: 2014). Model pembelajaran lain yaitumodel GI. Menurut Slavin (1995: 112)model GI adalah model pembelajaran yang melibatkan siswa secara aktif dalam pembelajarannya, para siswa mencari informasi dari berbagai sumber baik di dalam maupun di luar kelas. Jadi, siswa harus berpikir secara kritis, analitis, tepat dan bertindak kreatif, karena mereka harus mendesain suatu penemuan rumus.

Faktor selain model pembelajaran yang berpengaruh terhadap prestasi belajar siswa adalah kecerdasan emosional.Menurut Goleman (2007: 44-45) yang menyatakan bahwa setinggi-tingginya IQ menyumbang sekitar $20 \%$ bagi faktor yang menentukan sukses dalam hidup, maka yang $80 \%$ kesuksesan dipengaruhi oleh kecerdasan emosional. Mustaqim (2004: 152) menyatakan lima unsur kecerdasan emosional yaitu kesadaran diri, pengaturan diri, motivasi, mempunyai rasa empati, serta keterampilan sosial.Dengan kecerdasan emosional tinggi siswa mampu untuk bangkit dari kegagalan dalam meraih prestasi, memiliki keterampilan berinteraksi dengan orang lain, mampu mengatur emosi untuk mencapai tujuan dan cakap dalam memimpin diskusi. Kemampuan inilah yang mampu mengoptimalkan prestasi belajar siswa pada model PjBL dan model GI. Hal ini dikarenakan pada model PjBL dan GI menuntut tanggung jawab individu yang lebih besar dalam memahami suatu materi dan bekerja sama dalam suatu kelompok.

Kecerdasan emosional setiap siswa berbeda-beda maka faktor perbedaan kecerdasan emosional yang dimiliki siswa menarik untuk diteliti. Nwadinigwe dan Obieke (2012) menyatakan bahwa terdapat hubungan yang signifikan antara kecerdasan emosional dengan prestasi akademik dimana kecerdasan emosional seseorang berpengaruh terhadap kemampuan akademiknya. Penelitian ini untuk mengetahui seberapa jauh kecerdasan emosional siswa mempengaruhi keberhasilan prestasi belajar matematika siswa. Perbedaannya adalah peneliti menggunakan kecerdasan emosional sebagai tinjauan dengan model PjBL, model GI dan model pembelajaran langsung terhadap prestasi belajar, sedangkan Nwadinigwe dan Obieke hanya membuktikan secara empiris hubungan antara kecerdasan emosional dan prestasi akademik. Tujuan dari 
penelitian ini untuk mengetahui: (1) manakah model pembelajaran yang menghasilkan prestasi belajar matematika yang lebih baik antara model PjBL, GI atau pembelajaran langsung, (2) manakah yang memiliki prestasi belajar matematika yang lebih baik antara siswa dengan kecerdasan emosional tinggi, sedang atau rendah, (3) pada kecerdasan emosional tinggi, sedang atau rendah, manakah yang menghasilkan prestasi belajar matematika yang lebih baik antara model PjBL, GI atau pembelajaran langsung, (4) pada model PjBL, GI atau pembelajaran langsung, manakah yang memiliki prestasi belajar matematika yang lebih baik, siswa dengan kecerdasan emosional tinggi, sedang atau rendah.

\section{METODE PENELITIAN}

Penelitian ini dilaksanakan pada semester genap tahun pelajaran 2014/2015 pada materi bangun ruang dengan jenis penelitian eksperimental semu. Adapun desain faktorial pada penelitian ini disajikan dalam Tabel 1.

Tabel 1. Rancangan Penelitian

\begin{tabular}{lllll}
\hline \multirow{2}{*}{ Variabel bebas 2 } & Variabel bebas 1 & \multicolumn{3}{c}{ Kecerdasan Emosional(B) } \\
\cline { 2 - 5 } $\begin{array}{l}\text { Model } \\
\text { Pembelajaran }\end{array}$ & PjBL $\left(a_{1}\right)$ & $(a b)_{11}$ & $(a b)_{12}$ & $(a b)_{13}$ \\
\cline { 2 - 5 }$(\mathrm{A})$ & Cooperative tipe GI $\left(a_{2}\right)$ & $(a b)_{21}$ & $(a b)_{22}$ & $(a b)_{23}$ \\
\cline { 2 - 5 } & Langsung $\left(a_{3}\right)$ & $(a b)_{31}$ & $(a b)_{32}$ & $(a b)_{33}$ \\
\hline
\end{tabular}

Berdasarkan tabel 1, $(a b)_{11}$ adalah prestasi belajar siswa dengan kecerdasan emosional tinggi yang diberi perlakuan pembelajaran dengan menggunakan model PjBL. $(a b)_{12}$ adalah prestasi belajar siswa dengan kecerdasan emosional sedang yang diberi perlakuan pembelajaran dengan menggunakan model PjBL. $(a b)_{13}$ adalah prestasi belajar siswa dengan kecerdasan emosional rendah yang diberi perlakuan pembelajaran dengan menggunakan model PjBL. $(a b)_{21}$ adalah prestasi belajar siswa dengan kecerdasan emosional tinggi yang diberi perlakuan pembelajaran dengan menggunakan model GI. $(a b)_{22}$ adalah prestasi belajar siswa dengan kecerdasan emosional sedang yang diberi perlakuan pembelajaran dengan menggunakan model GI. $(a b)_{23}$ adalah prestasi belajar siswa dengan kecerdasan emosional rendah yang diberi perlakuan pembelajaran dengan menggunakan model GI. $(a b)_{31}$ adalah prestasi belajar siswa dengan kecerdasan emosional tinggi yang diberi perlakuan pembelajaran dengan menggunakan model pembelajaran langsung. $(a b)_{32}$ adalah prestasi belajar siswa dengan kecerdasan emosional sedang yang diberi perlakuan pembelajaran dengan menggunakan model pembelajaran langsung. $(a b)_{33}$ adalah prestasi belajar siswa dengan kecerdasan emosional rendah yang diberi perlakuan pembelajaran dengan menggunakan model pembelajaran langsung. 
Populasi dalam penelitian ini adalah seluruh siswa kelas VIII SMP Negeri se-Kota Metro. Sampel diambil dari populasi dengan teknik stratified cluster random sampling. Berdasarkan teknik pengambilan sampel tersebut, terpilih 3 sekolah sebagai sampel yaitu SMP Negeri 10 Metroyang mewakili sekolah tinggi, SMP Negeri 8 yang mewakili sekolah sedang dan SMP Negeri 5 Metroyang mewakili sekolah rendah.

Variabel dalam penelitian ini ada dua, yaitu variabel terikat dan variabel bebas. Variabel terikatnya adalah prestasi belajar matematika dan variabel bebasnya adalah model pembelajaran dan kecerdasan emosional siswa.Penelitian ini menggunakan model PjBLuntuk kelas eksperimen pertama, model GI untuk kelas eksperimen kedua dan model pembelajaran langsunguntuk kelas kontrol. Untuk mengumpulkan data digunakan metode dokumentasi, metode angket, dan metode tes.Metode dokumentasi digunakan untuk memperoleh data UN SMP se-Kota Metro tahun 2013/2014 untuk mengelompokkan sekolah dalam kategori tinggi, sedang, dan rendah. Selain itu, metode dokumentasi digunakan untuk memperoleh data mengenai kemampuan awal siswa berupa nilai ujian akhir semester ganjil Tahun Pelajaran 2014/2015 pada mata pelajaran matematika di sekolah-sekolah yang menjadi sampelpenelitian, data tersebut digunakan untuk uji keseimbangan.Metode angket digunakan untuk memperoleh data mengenai kecerdasan emosional siswa.Sedangkan metode tes digunakan untuk mengumpulkan data mengenai prestasi belajar matematika siswa.

Adapun teknik analisis data yang digunakan untuk menguji hipotesis dalam penelitian ini adalah analisis variansi dua jalan dengan sel tak sama. Sebelum masingmasing kelas diberikan perlakuan, terlebih dahulu dilakukan uji prasyarat terhadap data kemampuan awal siswa meliputi uji normalitas dengan menggunakan uji Lilliefors dan uji homogenitas variansi menggunakan uji Bartlett.Selanjutnya dilakukan uji keseimbangan dengan analisis variansi satu jalan untuk mengetahui apakah kelas eksperimen 1, kelas eksperimen 2 dan kelas kontrol berasal dari populasi yang mempunyai kemampuan awal seimbang atau tidak.

\section{HASIL PENELITIAN DAN PEMBAHASAN}

Setelah dilakukan uji keseimbangan untuk mengetahui kemampuan awal masingmasing kelompok adalah sama, selanjutnya dilakukan uji hipotesis penelitian. Rerata marginal dan reratamasing-masing sel dapat dilihat pada Tabel 2, sedangkanrangkuman hasil uji analisis variansi dua jalan dengan sel tak sama disajikan dalam Tabel 3. 
Tabel 2. Rerata Marginal dan Rerata Masing-Masing Sel

\begin{tabular}{|c|c|c|c|c|c|c|c|}
\hline \multirow{2}{*}{$\begin{array}{c}\text { Model } \\
\text { Pembelajaran } \\
\end{array}$} & \multicolumn{4}{|c|}{ Kecerdasan Emosional } & \multirow{2}{*}{\multicolumn{2}{|c|}{$\begin{array}{c}\text { Rerata } \\
\text { Marginal }\end{array}$}} & \multirow[b]{2}{*}{$n_{t o t}$} \\
\hline & Tinggi $\left(b_{1}\right)$ & & edang $\left(b_{2}\right)$ & Rendah $\left(b_{3}\right)$ & & & \\
\hline $\operatorname{PjBL}\left(a_{1}\right)$ & 77,67 & & 73,71 & $\begin{array}{l}58,43 \\
\end{array}$ & \multirow{2}{*}{\multicolumn{2}{|c|}{69,55}} & \\
\hline$n$ & 24 & & 28 & 28 & & & 80 \\
\hline GI $\left(a_{2}\right)$ & 74,72 & & 61,70 & 55,45 & \multirow{2}{*}{\multicolumn{2}{|c|}{64,05}} & \\
\hline$n$ & 25 & & 33 & 22 & & & 80 \\
\hline $\operatorname{Langsung}\left(a_{3}\right)$ & 63,14 & & 55,87 & 57,89 & \multirow{2}{*}{\multicolumn{2}{|c|}{58,97}} & 78 \\
\hline$n$ & 28 & & 31 & 19 & & & 10 \\
\hline Rerata Marginal & 71,43 & & 63,39 & 57,33 & & & \\
\hline$n_{\text {tot }}$ & 77 & & 92 & 69 & & & \\
\hline \multicolumn{8}{|c|}{ Tabel 3. Rangkuman hasil uji Analisis Variansi Dua Jalan } \\
\hline Sumber & $J K$ & $d k$ & $R K$ & $F_{\text {obs }}$ & $F_{\text {tabel }}$ & \multicolumn{2}{|c|}{ Keputusan } \\
\hline $\begin{array}{l}\text { Model } \\
\text { Pembelajaran (A) }\end{array}$ & 4659,047 & 2 & 2329,524 & 15,033 & 3,035 & \multicolumn{2}{|c|}{$H_{0 A}$ ditolak } \\
\hline $\begin{array}{l}\text { Kecerdasan } \\
\text { Emosional (B) }\end{array}$ & 8248,691 & 2 & 4124,345 & 26,615 & 3,035 & \multicolumn{2}{|c|}{$H_{0 B}$ ditolak } \\
\hline Interaksi (AB) & 2770,891 & 4 & 692,723 & 4,470 & 2,411 & \multicolumn{2}{|c|}{$H_{0 A B}$ ditolak } \\
\hline Galat & 35486,071 & 229 & 154,961 & - & - & \multirow{2}{*}{\multicolumn{2}{|c|}{ - }} \\
\hline Total & 51164,700 & 237 & - & - & - & & \\
\hline
\end{tabular}

Berdasarkan kolom keputusan pada Tabel 3 dapat disimpulkan sebagai berikut: (1) ada perbedaan rerata prestasi belajar siswa antar model pembelajaran, (2) ada perbedaan rerata prestasi belajar siswa antar kecerdasan emosional, (3) ada perbedaan rerata prestasi belajar siswa antar model pembelajaran dan kecerdasan emosional.

Hasil uji anava disimpulkan bahwaada perbedaan rerata prestasi belajar siswa antar model pembelajaran. Karena terdapat 3 model pembelajaran yaitu model PjBL, model GI dan model pembelajaran langsung, maka perlu dilakukan uji lanjut anava dengan metode Scheffe' untuk mengetahui adanya perbedaan rerata yang signifikan pada prestasi belajar siswa. Rangkuman hasil uji lanjut komparasi ganda antar baris dalam Tabel 4 berikut:

Tabel 4. Hasil Uji Komparasi Ganda Antar Baris

\begin{tabular}{cccc}
\hline$H_{0}$ & $F_{\text {obs }}$ & (2) $F_{0,05 ; 2 ; 229}$ & Keputusan \\
\hline$\mu_{1^{*}}=\mu_{2 \cdot}$ & 7,808 & 6,065 & $H_{0}$ ditolak \\
$\mu_{2^{*}}=\mu_{3^{*}}$ & 28,505 & 6,065 & $H_{0}$ ditolak \\
$\mu_{1^{*}}=\mu_{3^{*}}$ & 6,159 & 6,065 & $H_{0}$ ditolak \\
\hline
\end{tabular}

Berdasarkan kolom keputusan pada Tabel 4 dan rerata marginal pada Tabel 2, dapat disimpulkan bahwa model PjBL dapat menghasilkan prestasi belajar matematika lebih baik daripada model GI. Model GI dapat menghasilkan prestasi belajar matematika yang lebih baik daripada model pembelajaran langsung. Sesuai pendapat Aliurido (2008) bahwa pembelajaran matematika dengan menggunakan model Group Investigation menghasilkan prestasi belajar yang lebih baik dibandingkan pembelajaran matematika dengan menggunakan model langsung.Serta model PjBL dapat menghasilkan prestasi belajar matematika lebih baik daripada model pembelajaran langsung.

Hasil uji anava disimpulkan bahwaada perbedaan rerata prestasi belajar siswa antar kecerdasan emosional. Sehingga perlu dilakukan uji lanjut anava dengan metode Scheffe'. 
Rangkuman hasil uji lanjut komparasi ganda antar kolom dalam Tabel 5.

Tabel 5. Hasil Uji Komparasi Ganda Antar Kolom

\begin{tabular}{cccc}
\hline$H_{0}$ & $F_{\text {obs }}$ & $(2) F_{0,05 ; 2 ; 229}$ & Keputusan \\
\hline$\mu_{\mathrm{s} 1}=\mu_{\mathrm{s} 2}$ & 17,474 & 6,065 & $H_{0}$ ditolak \\
$\mu_{-2}=\mu_{s 3}$ & 46,656 & 6,065 & $H_{0}$ ditolak \\
$\mu_{-1}=\mu_{s 3}$ & 9,338 & 6,065 & $H_{0}$ ditolak \\
\hline
\end{tabular}

Berdasarkan kolom keputusan pada Tabel 5 dan rerata marginal pada Tabel 2, dapat disimpulkan bahwa siswa dengan kecerdasan emosional tinggi memiliki prestasi belajar lebih baik daripada siswa dengan kecerdasan emosional sedang, siswa dengan kecerdasan emosional sedang memiliki prestasi belajar lebih baik daripada siswa dengan kecerdasan emosional rendah, serta siswa dengan kecerdasan emosional tinggi memiliki prestasi belajar lebih baik daripada siswa dengan kecerdasan emosional rendah.Abdullah dkk.(2004) menyatakan bahwa pada siswa dengan emosional yang tinggi memiliki kemampuan dalam mengatur emosinya lebih baik dalam tes yang sedang dihadapinya.Selain itu, menurutYundari (2012)bahwa siswa dengan kecerdasan emosional tinggi prestasi belajar matematika lebih baik daripada siswa dengan kecerdasan emosional sedang dan rendah.

Hasil uji anava disimpulkan bahwaada perbedaan rerata prestasi belajar siswa antar model pembelajaran dan kecerdasan emosional. Hal ini berarti juga perludilakukan komparasi ganda antar sel. Rangkuman komparasi ganda antar sel pada kolom yang sama dalam Tabel 6.

Tabel 6. Hasil Uji Komparasi Ganda Antar Sel pada Kolom yang Sama

\begin{tabular}{cccc}
\hline$H_{0}$ & $F_{\text {obs }}$ & $(8) F_{0,05 ; 8 ; 229}$ & Keputusan \\
\hline$\mu_{11}=\mu_{21}$ & 0,686 & 15,832 & $H_{0}$ tidak ditolak \\
$\mu_{11}=\mu_{31}$ & 17,592 & 15,832 & $H_{0}$ ditolak \\
$\mu_{21}=\mu_{31}$ & 11,424 & 15,832 & $H_{0}$ tidak ditolak \\
\hline$\mu_{12}=\mu_{22}$ & 14,117 & 15,832 & $H_{0}$ tidak ditolak \\
$\mu_{12}=\mu_{32}$ & 30,227 & 15,832 & $H_{0}$ ditolak \\
$\mu_{22}=\mu_{32}$ & 3,501 & 15,832 & $H_{0}$ tidak ditolak \\
\hline$\mu_{13}=\mu_{23}$ & 0,703 & 15,832 & $H_{0}$ tidak ditolak \\
$\mu_{13}=\mu_{33}$ & 0,021 & 15,832 & $H_{0}$ tidak ditolak \\
$\mu_{23}=\mu_{33}$ & 0,392 & 15,832 & $H_{0}$ tidak ditolak \\
\hline
\end{tabular}

dapat disimpulkan bahwabagi siswa yang memiliki kecerdasan emosional tinggi, model PjBL menghasilkan prestasi belajar yang lebih baik daripada model pembelajaran langsung, sedangkan model PjBL dan model GI menghasilkan prestasi belajar yang sama, model GI dan model pembelajaran langsung menghasilkan prestasi belajar yang sama. Bagi siswa dengan kecerdasan emosional sedang, model PjBL menghasilkan prestasi belajar yang lebih baik daripada model pembelajaran langsung, sedangkan model PjBL 
dan model GI menghasilkan prestasi belajar yang sama, model GI dan model pembelajaran langsung menghasilkan prestasi belajar yang sama. Ketidakmampuan siswa dalam mengontrol atau mengendalikan emosinya juga berpengaruh pada motivasi belajar sehingga bisa jadi model pembelajaran yang dianggap lebih mampu meningkatkan prestasi belajar justru menghasilkan prestasi belajar yang sama dengan model pembelajaran yang dibandingkan (Preeti, 2013).Sedangkan bagi siswa dengan kecerdasan emosional rendah, model $\mathrm{PjBL}$, model GI dan model pembelajaran langsung menghasilkan prestasi belajar yang sama.

Uji lanjut pada model pembelajaran dapat dilihat pada rangkuman uji komparasi ganda antar sel pada baris yang sama disajikan pada Tabel 7.

Tabel 7. Hasil Uji Komparasi Ganda Antar Sel pada Baris yang Sama

\begin{tabular}{cccc}
\hline$H_{0}$ & $F_{\text {obs }}$ & $(8) F_{0,05 ; 8 ; 229}$ & Keputusan \\
\hline$\mu_{11}=\mu_{12}$ & 1,303 & 15,832 & $H_{0}$ tidak ditolak \\
$\mu_{11}=\mu_{13}$ & 30,865 & 15,832 & $H_{0}$ ditolak \\
$\mu_{12}=\mu_{13}$ & 42,219 & 15,832 & $H_{0}$ ditolak \\
\hline$\mu_{21}=\mu_{22}$ & 15,568 & 15,832 & $H_{0}$ tidak ditolak \\
$\mu_{21}=\mu_{23}$ & 28,029 & 15,832 & $H_{0}$ ditolak \\
$\mu_{22}=\mu_{23}$ & 3,319 & 15,832 & $H_{0}$ tidak ditolak \\
\hline$\mu_{31}=\mu_{32}$ & 5,020 & 15,832 & $H_{0}$ tidak ditolak \\
$\mu_{31}=\mu_{33}$ & 2,012 & 15,832 & $H_{0}$ tidak ditolak \\
$\mu_{32}=\mu_{33}$ & 0,002 & 15,832 & $H_{0}$ tidak ditolak \\
\hline
\end{tabular}

Berdasarkan kolom keputusan pada Tabel 7 dan rerata marginal pada Tabel 2, dapat disimpulkan bahwapada pembelajaran yang menggunakan model PjBL, siswa dengan kecerdasan emosional tinggi memiliki prestasi belajar lebih baik daripada siswa dengan kecerdasan emosional rendah, dan siswa dengan kecerdasan emosional sedang memiliki prestasi belajar lebih baik daripada siswa dengan kecerdasan emosional rendah. Nwadinigwe dan Obieke (2012) menyatakan bahwa terdapat hubungan yang signifikan antara kecerdasan emosional dengan prestasi akademik dimana kecerdasan emosional seseorang berpengaruh terhadap kemampuan akademiknya. Sedangkan pada pembelajaran yang menggunakan model $\mathrm{PjBL}$, siswa dengan kecerdasan emosional tinggi dan siswa dengan kecerdasan emosional sedang memiliki prestasi belajar yang sama. Pada pembelajaran yang menggunakan model GI, siswa dengan kecerdasan emosional tinggi memiliki prestasi belajar lebih baik daripada siswa dengan kecerdasan emosional rendah. Sedangkan siswa dengan kecerdasan emosional tinggi dan siswa dengan kecerdasan emosional sedang memiliki prestasi belajar yang sama, siswa dengan kecerdasan emosional sedang dan siswa dengan kecerdasan emosional rendah memiliki prestasi belajar yang sama. Pada pembelajaran dengan model pembelajaran langsung, siswa dengan kecerdasan emosional tinggi, siswa dengan kecerdasan emosional sedang 
dan rendah memiliki prestasi belajar yang sama. Hal ini karena kecerdasan emosional siswa tidak berpengaruh secara maksimal dalam proses pembelajaran di kelas.

\section{SIMPULAN DAN SARAN}

Berdasarkanpembahasan dari penelitian yang dilakukan, dapat disimpulkan sebagai berikut:(1) model PjBL dapat menghasilkan prestasi belajar matematika lebih baik daripada model GI dan model pembelajan langsung, model GI dapat menghasilkan prestasi belajar matematika lebih baik daripada model pembelajaran langsung, (2) siswa dengan kecerdasan emosional tinggi memiliki prestasi belajar matematika lebih baik daripada siswa dengan kecerdasan emosional sedang dan rendah, siswa dengan kecerdasan emosional sedang memiliki prestasi belajar matematika lebih baik daripada siswa dengan kecerdasan emosional rendah, (3) bagi siswa dengan kecerdasan emosional tinggi dan sedang, model $\mathrm{PjBl}$ menghasilkan prestasi belajar yang lebih baik daripada model pembelajaran langsung, sedangkan model PjBL dan model GI menghasilkan prestasi belajar yang sama, model GI dan model pembelajaran langsung menghasilkan prestasi belajar yang sama. Bagi siswa dengan kecerdasan emosional rendah, dengan model PjBL, model GI dan model pembelajaran langsung menghasilkan prestasi belajar yang sama, (4) pada pembelajaran yang menggunakan model PjBL, siswa dengan kecerdasan emosional tinggi memiliki prestasi belajar lebih baik daripada siswa dengan kecerdasan emosional rendah, dan siswa dengan kecerdasan emosional sedang memiliki prestasi belajar lebih baik daripada siswa dengan kecerdasan emosional rendah, sedangkan siswa dengan kecerdasan emosional tinggi dan siswa dengan kecerdasan emosional sedang memiliki prestasi belajar yang sama. Pada pembelajaran yang menggunakan model GI, siswa dengan kecerdasan emosioanl tinggi memiliki prestasi belajar lebih baik daripada siswa dengan kecerdasan emosional rendah. Sedangkan siswa dengan kecerdasan emosional tinggi dan siswa dengan kecerdasan emosional sedang memiliki prestasi belajar yang sama, siswa dengan kecerdasan emosional sedang dan siswa dengan kecerdasan emosional rendah memiliki prestasi belajar yang sama. Pada pembelajaran dengan model pembelajaran langsung, siswa dengan kecerdasan emosional tinggi, siswa dengan kecerdasan emosional sedang dan rendah memiliki prestasi belajar yang sama.

Adapun saran dari hasil penelitian ini yaitudalam pembelajaran matematika, guru lebih baik menggunakan model pembelajaran PjBL untuk meningkatkan prestasi belajar matematika, khususnya pada materi pokok bangun ruang. Selain itu, guru lebih baik mengetahui tingkat kecerdasan emosional masing-masing siswa sebelum melakukan pembelajaran sehingga guru dapat memilih model pembelajaran yang sesuai dan dapat 
mengoptimalkan prestasi belajar dari ketiga tingkatan kecerdasan emosional siswa. Hendaknya seorang guru sering menunjuk siswa dengan kecerdasan emosional rendah untuk maju menyampaikan hasil kerja kelompoknya agar lebih berani dan lebih kompak dengan kelompoknya.

\section{DAFTAR PUSTAKA}

Abdullah, M.E, Elias, H., Mahyuddin, R. and Uli, J. 2004. Emotional Intelligence and Academic Achievement among Malaysian Secondary Student.Pakistan Journal of Psychological Research,19 (3-4): 105-121.

Aliurido. 2008. Pembelajaran Group Investigation Pada Materi Pokok Persamaan dan Fungsi Kuadrat Ditinjau dari Motivasi Belajar Siswa (Studi Eksperimen Pada Siswa Kelas X MA Negeri di Kota Madiun). Tesis. Surakarta: PPs UNS.

Goleman, D. 2007. Emotional Intelligence. Jakarta: PT.Gramedia Pustaka Utama.

Hornby, G. 2009. The effectiveness of cooperative learning with trainee teachers.Journal of Education for Teaching, Vol 35 issue 2, page 161-168.

Ignacio, N., Nieto, L., and Barona, E. 2006. The Affective Domain In Mathematics Learning. International Electronic Journal of Mathemathics Education. October 2006, Vol. 1, No. 1, pp. 16-32.

Mustaqim. 2004. Psikologi Pendidikan. Yogyakarta: Pustaka Pelajar.

Nwadinigwe, I. P. and Obieke, A. U. 2012. The Impact of Emotional Intelligenceon Academic Achievement of Senior Secondary School Students in Lagos, Nigeria.Journal of Emerging Trends in Educational Research and Policy Studies (JETERAPS), 3(4): 395-401.

Permendikbud nomor 58. 2014. Kurikulum 2013 Sekolah Menengah Pertama. Jakarta: Pedoman Umum Pembelajaran.

Preeti, B. 2013.Role of Emotional Intelligence for Academic Achievement for Students.Research Journal of Education Sciences, 1(2): 8-12.

Slavin, R. 1995. Cooperative Learning: Theory, Research, and Practice. London: Allyn and Bacon.

Yundari. 2012. Eksperimentasi Pembelajaran Matematika dengan Model Cooperative learning Tipe Team Assisted Individualization (TAI) dan Team Games Tournaments (TGT) Ditinjau dari Kecerdasan Emosional Siswa SMA Negeri di Kabupaten Kudus Tahun Pelajaran 2011/2012. Tesis. Surakarta: PPs UNS. 